the boiling point at $0^{\circ}$. Celsius's diaries are preserved at the Observatory of Uppsala, and show the development of his experiments with thermometers. The centigrade scale with freezing point at zero and boiling point at $100^{\circ}$ appeared in 1747 on a thermometer bearing the name of its maker, the optician Ekström. It was constructed by Linnæus. In 1745, Linnæus had demonstrated to the Senate of the University his new thermometer, which in a letter to Sauvage he describes: "Ego primus fui, qui parare constitui thermometra nostra, ubi functum congelationis 0 et gradus coquentis aquae 100". It is strange that this centigrade thermometer of Linnæus, soon in universal use, and known at first as "the Swedish thermometer", should ever have become associated with the name of Celsius. But perhaps it was a casual association suggested by the C. for centigrade, together with the fact that Celsius was known to have experimented with thermometers.

\section{Public Relations Work}

IN a pamphlet entitled "Whither Public Relations Work?" Dr. William A. Hamor, of the Mellon Institute of Industrial Research, Pittsburgh, em. phasises the need of accumulations of facts about the social structure upon which public relations work rests, in order that the principles evolved will not crumble through faulty foundation work and therefore discourage this highly important managemental aid of the future. The development of such a science as sociology, especially for application in the province of public relations, requires investigators who are willing to achieve a thoroughly disinterested point of view toward the whole life of society for the purposes of their work. It is to be hoped that the day will soon come when an organisation may be established in which far-sighted social science research of a type corresponding in importance to physical science investigation may be carried forward extensively with the co-operation of management. When sociology has reached that plane of development, much of the guess-work that is now necessarymuch of that costly element of chance-will gradually be eliminated from management as a whole as well as from the direction of public relations activities.

\section{Re-awakening of Geysir at Hawkdale, Iceland}

After a sleep of nineteen years, Geysir, the hot spring in Iceland from the name of which the term 'geyser' was derived, has been awakened to renewed activity by three research workers, Trausti Einarsson, Jón Jónsson of Lang (Bath) and Gudmundur Gislason. The report of the revival of Geysir appeared in the Morgunblad of July 30, announcing the fact that magnificent jets were thrown up 40-50 metres high. Later, however, comes another account stating that Geysir spouted fifteen times on that day, that as of old the highest jets were delivered in the morning and about eleven o'clock at night. Eruptions are very sudden, preceded by bursts of steam, and, as it is dangerous to be near, sketches of these are more or less guess-work. Following the steam, water 'cascades' all around the crater, and the accompany- ing steam renders photographs or measurements useless. None of the jets has actually been measured. It was Dr. T. Einarsson who conceived the idea of awakening Geysir. He realised that the 'saucer' of the geysir was the most important factor concerned, providing a large surface of water from which heat was radiated as fast as it was supplied from below, thus preventing the accumulation of heat in the pipe below necessary to produce the outburst. Consequently a gap was made in the lip of the saucer to prevent the water spreading out. The experiment was justified, and Geysir continues its old activity. The road from Parliament Fields to Geysir, 118 kilometres in length, is to be improved, so that motor-cars may be able to undertake the journey.

\section{Speed and Engineering}

IN his presidential address to the Sheffield section of the Junior Institution of Engineers, Mr. Allan J. Grant gave an interesting account of the development of speed in engineering. Up to the advent of railways, about 1830 , a speed of about 30 miles an hour was the maximum. By the use of steam trains a speed of 100 miles an hour was made safe. In 1933 the motor-car Bluebird did 272 miles per hour. The motor-boat Miss Britain $I I I$ recently attained a speed of 111 miles per hour. To attain this speed, 1,375 horse-power had to be transmitted through a shaft only $1_{\frac{1}{8}}^{1}$ in. in diameter. At the outbreak of the War, the most advanced aeroplane engines developed about 100 brake horse-power, and weighed about $4 \mathrm{lb}$. per horse-power, and the average speed varied from 60 miles to 90 miles per hour. The modern 'sprint' engines run at more than 3,000 rev. per min. and weigh only $\frac{2}{3}$ lb. per b.h.p. The recent flight of Charles Ulm to Australia in 6 days 18 hours proves the capabilities of small aircraft. Jules Verne's speed in "Round the World in 80 Days" is no longer fantastic. In fact, velocities would only have to be slightly more than doubled to become 1,000 miles an hour. At this speed, it would be possible for an airman starting at the equator at sunrise and flying west to arrive in 24 hours at sunrise and have continuous sunrise all the way round. If he flew in the latitude of London he would only have to fly at 620 m.p.h. to obtain the same effect. At the present time, it would not be possible for him to carry sufficient fuel for the purpose.

\section{Railway Electrification}

IN an address broadcast from Radio Paris on May 16 and published in Le Genie Civil for June 22, Prof. H. Parodi says that the problem of railway electrification has come to the forefront in all the countries of the world. Between 1927 and 1933 more than 6,800 miles were electrified throughout the world, more than 3,000 being in Europe. The electrification of the Paris-Orleans, Orleans-Tours and Vierzon-Brive railway is an excellent example of main-line electrification, as all the services, signals, illumination, etc., are carried out electrically. Every discovery in the realm of power-production accelerates 
the spread of electrification. In electric power stations, lignite, oil, coke-oven and blast furnace gas are used as well as coal and water-power. In France, electrification is from certain points of view imperative as France has to purchase coal and oil from abroad whilst it possesses great internal water-power resources. The consumption of fuel by French railways amounts to 42 million tons, of which 30 millions has to be imported. At the present time, France utilises 8,000 million kilowatt hours of energy generated by water-power or about 20 per cent of its maximum potential water-power resources. In Italy the policy of exploiting the natural wealth of the country has been systematically pursued. More than 1,200 miles of Italian railways are electrified and 3,000 miles are in progress. Similar, but less far-reaching programmes, have been prepared and are being carried out in Switzerland, Sweden and Bavaria. The electrical machinery employed is almost entirely automatic and entails operation, maintenance and repair charges considerably lower than steam locomotives.

\section{Centenary of the Great Western Railway}

ON August 31, 1835, after an unduly protracted and very expensive Parliamentary struggle, the Royal Assent was given to the Bill authorising the construction of the railway between Bristol and London, to which two years earlier the name of the Great Western Railway had been given. Notable among British railways for many reasons, the Great Western Railway as it is to-day has a fine record of achievement, and last week the centenary of the passing of the Bill which brought it into being was commemorated in various ways. On the evening of August 30, the B.B.C. included in its programme an account of the railway and its many activities, while on August 31, The Times issued a Great Western Railway Centenary Number as a special supplement, of 28 full-sized pages. The forty articles in this supplement include not only sketches of the history of the line, a biography of Brunel and a review of locomotives and rolling stock, but also others dealing with co-operation in transport, speed, safety and comfort in travel and the organisation of a great railway. As is well known, when planning the Great Western line, Brunel adopted the $7 \mathrm{ft}$. or broad gauge, as compared with the $4 \mathrm{ft}$. $8 \frac{1}{2} \mathrm{in}$. or narrow gauge, as used by the Stephensons and others, and it was this that gave rise to the famous "battle of the gauges". When that battle was at its height, a Royal Commission reported that the broad gauge was superior for speed and steady running, and for the greater capacity of the engines, but as there were then 1900 miles of narrow gauge line in existence as compared with only 274 miles of broad gauge, the verdict was given in favour of the former. This and other matters are all dealt with in an interesting manner in The Times supplement, which will remain of permanent value to all students of transport.

\section{International Commission of Agriculture}

The International Commission of Agriculture (International Union of Agricultural Associations) recently held its general assembly at Brussels and
Gembloux (Belgium) under the chairmanship of the Marquis de Vogüé (France), president. Among the problems discussed were the organisation of agricultural production under planned economy, edible fats, limitation of pig breeding and fattening (with special reference to attempts made in Denmark and Holland). The assembly devoted special attention to the present condition of agriculture. It came to the conclusion that in spite of the fact that useful measures have been taken in several countries since 1932, conditions of agriculture have grown worse. The Commission is convinced that the two main problems to be solved in order to overcome the agricultural crisis are the wheat problem and the edible fats problem : on one hand the London Wheat Agreement (1933) should be prolonged and improved; on the other, the older civilised countries should take measures or improve the existing measures in order to prevent consumption of tropical fats and whale oil, which handicaps the normal production and consumption of butter and lard. The Commission will hold its next meeting in 1936, in Oslo. It has been decided that the twelfth International Congress of Agriculture shall take place at The Hague in 1937.

\section{Religious Motives in Medical Biology}

IN the April issue of the Bulletin of the Institute of the History of Medicine Dr. Walter Pagel deals successively with the doctrines of Paracelsus, Hieronymus Hirnhaim, the alchemists of the seventeenth century and their adversaries, Marcus Marci, Robert Fludd, Mersenne and Robert Boyle, to illustrate the presence of religious motives in the medical biology of the seventeenth century. Dr. Pagel first shows that to Paracelsus and his religious view is due the modern conception of disease in the establishment of three new doctrines, namely: (1) the external cause is the essence of disease; (2) the organ involved and the anatomical changes decide the nature of the disease ; and (3) disease consists of a complicated disturbance of organ metabolism which secondarily reflects upon the whole system. Hirnhaim, who regarded sympathy and antipathy as fundamental phenomena, adopted a pious scepticism which was the philosophical basis of idealistic biology and pathology. On the other hand, the pious conceptions of Nature and magic in the writings of the seventeenth century alchemists led to their embarking on a course of independent empirical research, their point of view being partly due to a positive apprecia. tion of magic as a systematic imitation of Nature by means of arbitrary variation of the conditions of natural processes. After discussing the speculative embryology of Marcus Marei and his application of the physics of light to the explanation of life according to the principles of optics, Dr. Pagel gives an account of the "Medicina Catholica" of Robert Fludd, and shows at once the similarity of his conceptions with, and the fundamental differences from, the Romantic natural philosophy during the early nineteenth century. In conclusion, consideration is given to Robert Boyle and his theory of corpuscles as a scientific explanation of the mystery of specificity, forms and final causes. 